(c) American Dairy Science Association, 2005.

\title{
Feeding Patterns and Performance of Cows in Controlled Cow Traffic in Automatic Milking Systems
}

\author{
M. Melin, K. Svennersten-Sjaunja, and H. Wiktorsson \\ Department of Animal Nutrition and Management, \\ Swedish University of Agricultural Sciences, Uppsala, Sweden
}

\begin{abstract}
Two groups of dairy cows monitored from 3 to $19 \mathrm{wk}$ postpartum were subjected to 2 different cow traffic routines in an automatic milking system with control gates and an open waiting area. Using different time settings in the control gates, the groups of cows were separated by average milking frequency; cows in the high milking frequency routine had a minimum of $4 \mathrm{~h}$ between milkings $\left(\mathrm{MF}_{4}\right)$ and were milked $3.2 \pm 0.1$ times daily, whereas cows in the low milking frequency routine had at least $8 \mathrm{~h}$ between milkings $\left(\mathrm{MF}_{8}\right)$ and were milked $2.1 \pm 0.1$ times daily. Cows in the 2 groups were switched to the opposite milking frequency control for wk 18 and 19. The increased milking frequency resulted in a higher milk yield of about $9 \%$ through 16 wk of early lactation Although the higher milk yield was not significant when measured as energy-corrected milk, significant interactions of milking frequency and study period for milk yield and energy-corrected milk yield were consistent with a yield response when cows were milked more frequently. Meal criteria estimated for each individual cow were used to group feeding visits into meals. During $\mathrm{MF}_{4}$, cows fed in fewer meals per day and had longer meals than during $\mathrm{MF}_{8}$. The control gates were used efficiently, with only a few passages not resulting in actual meals. Although the voluntary meal intervals seemed to be short, the average milking frequency was far below that theoretically possible. This was explained by individual differences in milking frequency and long intervals from when a cow was redirected in a control gate until it arrived in the milking unit. A wide individual range in the voluntary interval between the first and the second meal in the milking cycle suggests that fixed time limits for control gates set on group level have no justifiable biological basis. It was also concluded that primiparous cows were well adapted to the automatic milking system after $2 \mathrm{wk}$ in the barn.
\end{abstract}

Received February 3, 2005.

Accepted June 20, 2005.

Corresponding author: Martin Melin; e-mail: martin.melin@huv. slu.se.
(Key words: automatic milking, feeding pattern, individual management, milking frequency)

Abbreviation key: AMS = automatic milking system, $\mathbf{E C M}=$ energy-corrected milk, $\mathbf{G}_{\mathbf{4}-\mathbf{8}}=$ treatment group started at the high milking frequency routine and shifted to the lower frequency, $\mathbf{G}_{\mathbf{8 - 4}}=$ treatment group started at the low milking frequency routine and shifted to the higher frequency, $\mathbf{M E}=$ metabolizable energy, $\mathbf{M F}{ }_{4}=$ milking frequency routine with a minimum milking interval of $4 \mathrm{~h}, \mathbf{M F}_{\mathbf{8}}=$ milking frequency routine with a minimum milking interval of $8 \mathrm{~h}, \mathbf{P P}=$ postpartum.

\section{INTRODUCTION}

The milk yield of dairy cows is positively related to milking frequency. Automatic milking systems (AMS) allow for increased milking frequency, and thereby, an expected increase in milk yield. To increase the milking frequency of cows held in AMS, different ways to control the cow traffic have been developed. Motivation to feed is a better incentive in attracting the cows to the milking unit than the motivation to be milked (Prescott et al., 1998; Halachmi et al., 2000). The motivation to feed is used in controlled cow traffic, which implies that the cows are guided to the feeding area via the milking unit. In this way, the number of visits to the milking unit is dependent on the voluntary feeding patterns of the cows. Feed intake of the dairy cow is not a continuous process-cows feed in distinct bouts or meals (Metz, 1975). Studies of feeding patterns in the short term (from one meal to the next) can provide a better understanding of feed intake regulation (Tolkamp et al., 2002).

The short-term feeding patterns of dairy cows determine the number of voluntary visits to the feeding area in an AMS. The cow traffic control system decides, for each voluntary visit, if the cow should have a milkingrelated meal or a nonmilking-related meal. In this way, the cow is fed and milked according to its individual feeding pattern. The feeding strategy applied in the herd and the AMS design have been shown to affect the cow traffic; the number of voluntary visits to the 
feeding area was influenced by the diet (Rodenburg and Wheeler, 2002), the design of the AMS influenced the time that the cows spent feeding per day (Hermans et al., 2003), and the degree of controlled cow traffic had effects on voluntary visits to the feeding area and the daily feed intake (Harms et al., 2002). Management practices that influence the short-term feeding pattern may also affect voluntary visits to the feeding area. Knowledge on how short-term feeding patterns of dairy cows are affected by feeding strategies and AMS design is a prerequisite for development of efficient cow traffic systems.

Alteration in milking frequency can be used to affect milk production, and is, therefore, an important management tool in the AMS (Devir and Maltz, 1995). Increases in milk yield result in a higher demand of feed intake to compensate for the higher energy output of the cow. If the cow cannot compensate for the increased energy output by increasing its feed intake, an elevated energy drain with a loss of BW will follow (Bar-Peled et al., 1995). Considering the central role that DMI plays in the etiology of metabolic diseases in the early postpartum period (Drackley, 1999), the design of AMS should not only have increased yield as an aim, but also allow for high feed intake.

There exists little information on adaptations of feeding patterns of dairy cows in response to controlled cow traffic in AMS. Further, the production effects due to increased milking frequency in AMS have been shown to be positive (Svennersten-Sjaunja et al., 2000) and negative (Poelarends et al., 2004). The objectives of this study were to investigate the effects on production, feed intake, and feeding patterns when 2 different cow traffic routines were applied in an AMS with control gates and an open waiting area.

\section{MATERIALS AND METHODS}

\section{General}

The study was performed at the Swedish University of Agricultural Sciences in Uppsala, Sweden. Thirty Swedish Red and White dairy cows (10 primiparous cows and 20 multiparous cows) were included in the study. Two cows were removed from the barn before the study had ended because of sickness. Another 2 cows were let out on pasture before the study had ended (according to Swedish legislation, all dairy cows must be let out on pasture in the summertime). The average bulk SCC of the herd during the study period was 102,000 (SD 53,000) cells $/ \mathrm{mL}$ of milk. The cows were loose-housed in a barn provided with an automated milking unit, and were kept indoors throughout the study period (September 2001 to April 2002). The barn was a loose-housing system including a free-stall area

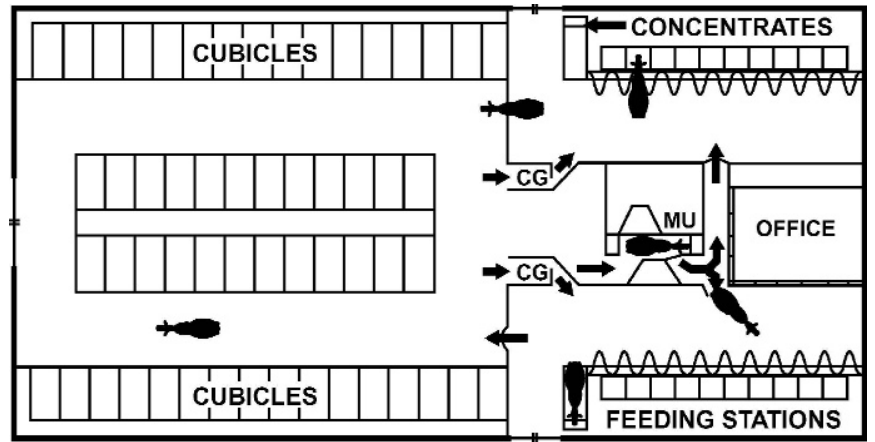

Figure 1. Schematic drawing of the experimental barn layout. $\mathrm{CG}=$ control gate; $\mathrm{MU}=$ automated milking unit; Cubicles $=$ freestalls.

with 54 free-stalls, 2 separate feeding areas, and a milking compartment. From the free-stall area, cows could enter either of the 2 feeding areas through either of the 2 control gates or through the automated milking unit. Barn layout is presented in Figure 1. Cows exited feeding areas through self-closing gates. In each of the 2 feeding areas, 10 roughage feeding stations were available with mixed feed (Biocontrol A/S, Rakkestad, Norway), 1 concentrate feeding station (DeLaval AB, Tumba, Sweden), 1 mineral bucket, 1 salt lick, and 1 water bowl. Another 4 water bowls were placed in the free-stall area.

The milking compartment consisted of 1 automated milking unit (DeLaval VMS) and an open waiting area of $40 \mathrm{~m}^{2}$ in front of the unit entrance. The milking unit was accessible $24 \mathrm{~h} / \mathrm{d}$, except at times for system cleaning and milk handling. Those inaccessible periods occurred for $30 \mathrm{~min}$ at 0900 and at $1300 \mathrm{~h}$, and for 60 min at $0200 \mathrm{~h}$. All areas of the barn were illuminated at night.

\section{Feeds and Feeding}

After entrance into the feeding areas, cows were offered ad libitum mixed feed (grass-clover silage and concentrate, ratio $75: 25$ on a DM basis) in automated roughage feeding stations, a daily maximum of $2.0 \mathrm{~kg}$ of DM hay in a separate roughage feeding station, and concentrate supplied in the milking unit and in concentrate feeding stations. In the milking unit, cows were fed $0.3 \mathrm{~kg}$ of concentrate at each milking, and in the concentrate stations, a maximum daily amount of 10 $\mathrm{kg}$ was fed depending on parity and stage of lactation. The concentrate contained (as percentage of total DM) $30 \%$ barley, $20 \%$ oats, $16 \%$ rapeseed meal, $14 \%$ soybean meal, $14 \%$ beet pulp, $4 \%$ wheat bran, and $2 \%$ mineral mix. The silage consisted of a mix of fescue, timothy, and a small proportion of red clover. A representative 
Table 1. Average values ( \pm SD) of qualitative measurements of the feeds used in the study.

\begin{tabular}{lccr}
\hline Measure & \multicolumn{1}{l}{ Hay } & Concentrate & Grass silage \\
\hline Metabolizable energy, ${ }^{1}$ MJ/kg of DM & $11.2 \pm 0.4$ & 12.0 & $11.2 \pm 0.2$ \\
CP, g/kg of DM & $122.0 \pm 6.1$ & 220.0 & $143.4 \pm 9.4$ \\
DM, \% of DM & $87.4 \pm 1.1$ & 89.4 & $40.2 \pm 3.7$ \\
$\mathrm{NH}_{3}, \%$ of total nitrogen & - & - & $4.5 \pm 1.1$ \\
$\mathrm{pH}$ & - & - & $4.3 \pm 0.2$ \\
\hline
\end{tabular}

${ }^{1}$ Spörndly (1999).

sample was taken once a week for analysis of the quality of the silage. Quality measures of the silage, the hay, and the concentrate are presented in Table 1.

The average total number of cows in the barn during the period was 45 (SD 4.4). Cows were observed for the first part of lactation beginning 8 to $19 \mathrm{~d}$ postpartum (PP). Before entering the AMS, the cows spent the first 4 to $5 \mathrm{~d} \mathrm{PP}$ in a pen together with their calves and were then transferred to a tie-stall, where they spent another 4 to $10 \mathrm{~d}$ for continual health control. After this period, they were introduced into the experimental AMS. Cows were milked $2 \times$ daily before beginning the experiment. Cows were exposed to the AMS during previous lactation(s) or $3 \mathrm{wk}$ before first calving. In addition, the first 2 wk after introduction to the AMS were considered an adaptation period and not included in the analysis.

\section{Experimental Design}

The treatment in the present study was 2 different degrees of controlled cow traffic, which aimed at guiding the cows to either a high or a low average milking frequency. The cows were subjected to 2 different minimum time limits between milking events. If entering the milking area within a period less than the set time limit, the cows were not permitted to be milked, but they had access to the feeding areas through the control gates. If they were not permitted to be milked, the cows were allowed to walk through the milking unit to the feeding area. Beyond this time limit, the cows first must have entered the milking unit to be milked before accessing the feeding area. A cow trying to pass a control gate when beyond the time limit was redirected (gate remained closed) to the waiting area. The high milking frequency routine $\left(\mathbf{M F}_{4}\right)$ allowed a minimum of $4 \mathrm{~h}$ between milking events (maximum of 6 milkings per $24 \mathrm{~h}$ ), whereas the low milking frequency routine $\left(\mathbf{M F}_{\mathbf{8}}\right)$ allowed $8 \mathrm{~h}$ (maximum of 3 milkings per $24 \mathrm{~h}$ ). The study was divided into 3 periods; period 1 lasted from wk 3 through $10 \mathrm{PP}$; period 2 lasted from wk 11 through 16; and period 3 included wk 18 and $19 \mathrm{PP}$. The cows were assigned randomly according to parity (primiparous vs. multiparous) to 1 of 2 groups. In one group, cows were subjected to $\mathrm{MF}_{4}$ during periods 1 and 2 of the study and switched to $\mathrm{MF}_{8}$ during period $3\left(\mathbf{G}_{\mathbf{4 - 8}}\right)$. Cows in the other group were subjected to $\mathrm{MF}_{8}$ during periods 1 and 2 and switched to $\mathrm{MF}_{4}$ during period 3 $\left(\mathbf{G}_{8-4}\right)$. When the data were analyzed, the first $2 \mathrm{wk}$ in period 1 of the study were not included such that data for the first 2 periods were from 6 wk each (wk 5 to 10 $\mathrm{PP}$ and wk 11 to $16 \mathrm{PP}$ ). Cows not milked by the AMS within 9 or $14 \mathrm{~h}$ for $\mathrm{MF}_{4}$ and $\mathrm{MF}_{8}$ cows, respectively, were manually brought to the automated milking unit for milking twice daily (0500 and $1730 \mathrm{~h}$ ).

\section{Data Acquisition}

When a cow entered the roughage station for feeding, the front bar lowered to give access to feed in the trough; cow identity, starting time of the visit, and the weight of the feed trough were recorded. When a cow withdrew from the station, the bar rose to prevent unauthorized feed consumption by another cow, and the stop-time of the visit and the weight of the feed trough were again recorded.

The concentrate feeding stations consisted of a concentrate dispenser, an antenna for cow identification, scales for animal weight registration, and an automatic gate. This gate was automatically closed behind a cow that entered the feeding station to protect from batting by barn mates during feeding. The gate stayed closed as long as the cow kept its head in the feed dispenser trough (and assuming the cow had permission to eat concentrate). Each entrance to the concentrate feeding stations produced a data log containing cow identification, time of entrance, total feeding time, the weight of delivered feed, and animal weight.

Time of passage and redirection in control gates, milk yield, and time of milking were electronically registered in the AMS. Once a week, milk samples were collected from each milking over $24 \mathrm{~h}$. Milk samples were analyzed for fat, protein, and lactose content using midinfrared spectroscopy (Milkoscan 5000, Foss Electric, Hillerød, Denmark). The cows were scored for body condition once every second week using a 5-point scale (including half points), where $1=$ emaciated and $5=$ obese. Data from roughage feeding stations, concentrate feeding stations, water bowls, control gates, and 
the milking unit were transferred automatically to a database for storage and analysis.

\section{Data Handling and Statistical Analyses}

Cows have been shown to eat in distinct meals, and each meal consists of a number of visits to the feeding troughs. Meal criteria, i.e., the longest interval not separating 2 meals, were estimated in accordance to Melin et al. (2005). In the present study, a meal criterion was estimated for each individual cow; 17 of the cows showed evidence of having 3 populations and were therefore modeled in a mixture of 2 Gaussian and 1 Weibull distributions; 13 of the cows showed no evidence of having a third population and were therefore modeled in a mixture of 1 Gaussian and 1 Weibull distribution. The average meal criterion for the 30 cows was 40.5 min (SD 15.1).

Data on feeding pattern measures, cow traffic measures, milk production, and feed intake were calculated for each cow and day, and averaged over periods of 7 d. This resulted in observations for 14 wk per cow that were used in the analyses. Data were analyzed in model 1 using procedure MIXED in SAS 8.02 (SAS Institute, 1999):

$$
\begin{gathered}
Y_{i j k b m}=\mu+\alpha_{i}+\beta_{j}+\delta_{k}+\pi_{l}+\alpha \delta_{i k} \\
+\beta \delta_{j k}+\alpha \beta_{i j}+\tau_{m}+\varepsilon_{i j k l m}
\end{gathered}
$$

where $Y_{i j k l m}=$ variable of interest, assumed normally distributed with mean $\mu$ and variance $\sigma^{2}, \alpha_{i}=$ the fixed effect of milking frequency routine $\mathrm{i}\left(\mathrm{MF}_{4}\right.$ or $\left.\mathrm{MF}_{8}\right), \beta_{j}=$ the fixed effect of parity $\mathrm{j}$ (primiparous or multiparous), $\delta_{k}=$ the fixed effect of period (period 1 to period 3$), \pi_{l}=$ the fixed effect of week in lactation 1 nested within period, $\tau_{m}=$ the random effect of cow $\mathrm{m}$ nested within treatment and parity ( 1 to 30 ), and $\varepsilon_{i j k l m}=$ the random error term. The number of degrees of freedom was estimated with the Satterthwait method (SAS Institute, 1999). After significant $F$-tests $(P<0.05)$, estimated least squares means were compared in pairwise $t$-tests at the $5 \%$ level (unless otherwise stated). The interaction between milking frequency routine parity was dropped if not significant.

Redirection time was calculated as the elapsed time from that a cow was redirected in a control gate until it entered the milking unit. Because the distribution of redirection time was skewed, the mean value was calculated on natural logarithmic data. Return time was defined as the elapsed time from a milking to the first attempt to make a nonmilking related feeding meal by register in a control gate (i.e., the elapsed time for the following sequence of incidents: milking $\rightarrow$ milking- related meal $\rightarrow$ end of milking-related meal $\rightarrow$ passage/ redirection in control gate).

The difference between metabolizable energy (ME) intake from feed and ME needed for maintenance, milk production, and the observed BW change was calculated in accordance to the Swedish feeding standard (Spörndly, 1999). Total ME needed was calculated as $1.11 \times$ (sum of ME for maintenance and milk production) - 13.6. Metabolizable energy for maintenance was 0.507 $\mathrm{MJ} / \mathrm{kg}$ of metabolic BW (BW $\left.{ }^{0.75}\right)$, ME for milk production was $5 \mathrm{MJ} / \mathrm{kg}$ of energy-corrected milk (ECM) (Sjaunja et al., 1990), and ME needed for $1 \mathrm{~kg}$ of increase in BW was 34.5 MJ of ME. The difference was calculated on estimated group means of feed intake and production for period 2, in which the observed BW change was less influenced by variation in gut fill.

\section{RESULTS}

\section{Measures Related to Milk Production and Feed Intake}

Measures related to milk production and feed intake are presented in Table 2. Cows in $\mathrm{G}_{4-8}$ produced 8.7\% more milk than did cows in $\mathrm{G}_{8-4}$ during period $1(P<$ 0.1 ) and $10.6 \%$ more milk than did cows in $\mathrm{G}_{8-4}$ during period 2. When measured in kilograms of ECM, the $\mathrm{G}_{4-8}$ group tended to produce $8.9 \%$ more milk than did $\mathrm{G}_{8-4}$ in period $2(P<0.1)$. There was a significant drop in the production of cows in $\mathrm{G}_{4-8}$ in period 3 compared with period 2, whereas cows in $\mathrm{G}_{8-4}$ maintained milk production when shifted to the more frequent schedule during period 3. Therefore, milk and ECM yields of cows in both $\mathrm{G}_{8-4}$ and $\mathrm{G}_{4-8}$ were similar during period 3 , resulting in significant interactions for period and milking frequency. Average milk fat content was $4.6 \%$, milk protein content $3.3 \%$, and average milk lactose content was $4.9 \%$. There were no significant fixed effects for milk composition. Primiparous cows produced less than multiparous cows, and there was an overall effect of parity for total DMI and DMI of mixed feed. There were no significant treatment effects for total DMI and DMI of mixed feed in any of the 3 periods.

After subtracting ME needs from total ME intake from feed, remaining $\mathrm{ME}$ was $13.4 \mathrm{MJ} / \mathrm{d}$ for $\mathrm{G}_{4-8}$ and $31.1 \mathrm{MJ} / \mathrm{d}$ for $\mathrm{G}_{8-4}$. The observed $\mathrm{BW}$ change of the $\mathrm{G}_{4-8}$ cows was on average $0.43 \mathrm{~kg} / \mathrm{d}$, which resulted in a negative balance of $-2.0 \mathrm{MJ} / \mathrm{d}$. The observed $\mathrm{BW}$ change of the $\mathrm{G}_{8-4}$ cows was on average $0.57 \mathrm{~kg} / \mathrm{d}$, which resulted in a positive balance of $10.7 \mathrm{MJ} / \mathrm{d}$. Cows in both milking frequency routines had gained somewhat in body condition at the end of the study but there were no significant differences in BCS. 
Table 2. Least squares means and standard errors (SE) for cows of different milking frequency treatments (MF) and parities (PA) for total DM intake (TDMI), DM intake of mixed feed (MDMI), milk yield (MY), energy corrected milk (ECM) and BCS. Data presented for each period (P).

\begin{tabular}{|c|c|c|c|c|c|c|c|c|}
\hline & \multirow[b]{2}{*}{$\mathrm{MF} / \mathrm{PA}^{1}$} & \multicolumn{3}{|c|}{ Period } & \multicolumn{3}{|c|}{ Type II SS $P>\mathrm{F}$} & \multirow[b]{2}{*}{$\mathrm{PA} \times \mathrm{P}$} \\
\hline & & $\begin{array}{l}1 \\
\text { (wk 5-10) }\end{array}$ & $\begin{array}{l}2 \\
\text { (wk 11-16) }\end{array}$ & $\begin{array}{l}3 \\
\text { (wk 18-19) }\end{array}$ & $\mathrm{MF}$ & PA & $\mathrm{MF} \times \mathrm{P}$ & \\
\hline \multirow[t]{4}{*}{ TDMI, kg/d } & $\mathrm{G}_{4-8}$ & $21.4(0.5)$ & $22.5(0.5)$ & $21.1(0.7)$ & \multirow[t]{4}{*}{0.82} & \multirow[t]{4}{*}{0.001} & \multirow[t]{4}{*}{0.31} & \multirow[t]{4}{*}{0.17} \\
\hline & $\mathrm{G}_{8-4}$ & $21.7(0.5)$ & $22.0(0.5)$ & $21.9(0.7)$ & & & & \\
\hline & Primi & $19.4(0.6)$ & $19.9(0.6)$ & $19.8(0.8)$ & & & & \\
\hline & Multi & $23.7(0.4)$ & $24.6(0.4)$ & $23.2(0.6)$ & & & & \\
\hline \multirow[t]{4}{*}{ MDMI, kg/d } & $\mathrm{G}_{4-8}$ & $14.5(0.4)$ & $14.8(0.4)$ & $14.3(0.6)$ & \multirow[t]{4}{*}{0.52} & \multirow[t]{4}{*}{0.001} & \multirow[t]{4}{*}{0.34} & \multirow[t]{4}{*}{0.07} \\
\hline & $\mathrm{G}_{8-4}$ & $15.1(0.4)$ & $14.6(0.4)$ & $14.9(0.6)$ & & & & \\
\hline & Primi & $13.2(0.5)$ & $13.0(0.5)$ & $13.8(0.7)$ & & & & \\
\hline & Multi & $16.3(0.3)$ & $16.5(0.3)$ & $15.4(0.5)$ & & & & \\
\hline \multirow[t]{4}{*}{ MY, kg/d } & $\mathrm{G}_{4-8}$ & $33.8(1.0)^{\mathrm{a} * *}$ & $33.3(1.0)^{\mathrm{a} *}$ & $30.1(1.2)^{\mathrm{b}}$ & \multirow[t]{4}{*}{0.19} & \multirow[t]{4}{*}{0.001} & \multirow[t]{4}{*}{0.001} & \multirow[t]{4}{*}{0.001} \\
\hline & $\mathrm{G}_{8-4}$ & $31.1(1.0)^{\mathrm{a}}$ & $30.1(1.0)^{\mathrm{b}}$ & $30.3(1.1)^{\mathrm{b}}$ & & & & \\
\hline & Primi & $26.1(1.2)^{\mathrm{a} *}$ & $26.9(1.2)^{\mathrm{a} *}$ & $26.7(1.4)^{\mathrm{a} *}$ & & & & \\
\hline & Multi & $38.9(0.9)^{\mathrm{a}}$ & $36.6(0.9)^{\mathrm{b}}$ & $33.7(0.9)^{\mathrm{c}}$ & & & & \\
\hline \multirow[t]{4}{*}{ ECM, kg/d } & $\mathrm{G}_{4-8}$ & $36.1(1.0)^{\mathrm{a}}$ & $35.4(1.1)^{\mathrm{a} * *}$ & $32.2(1.3)^{\mathrm{b}}$ & \multirow[t]{4}{*}{0.37} & \multirow[t]{4}{*}{0.001} & \multirow[t]{4}{*}{0.001} & \multirow[t]{4}{*}{0.001} \\
\hline & $\mathrm{G}_{8-4}$ & $33.9(1.1)^{\mathrm{a}}$ & $32.5(1.1)^{\mathrm{b}}$ & $33.2(1.2)^{\mathrm{b}}$ & & & & \\
\hline & Primi & $28.6(1.3)^{\mathrm{a} *}$ & $29.0(1.3)^{\mathrm{b} *}$ & $29.1(1.5)^{\mathrm{c} *}$ & & & & \\
\hline & Multi & $41.4(0.9)^{\mathrm{a}}$ & $38.9(0.9)^{\mathrm{b}}$ & $36.3(1.1)^{\mathrm{c}}$ & & & & \\
\hline \multirow[t]{4}{*}{ BCS } & $\mathrm{G}_{4-8}$ & $2.5(0.2)$ & $2.8(0.2)$ & $3.0(0.2)$ & \multirow[t]{4}{*}{0.31} & \multirow[t]{4}{*}{0.68} & \multirow[t]{4}{*}{0.58} & \multirow[t]{4}{*}{0.57} \\
\hline & $\mathrm{G}_{8-4}$ & $3.0(0.2)$ & $2.9(0.2)$ & $3.2(0.2)$ & & & & \\
\hline & Primi & $2.7(0.3)$ & $2.8(0.3)$ & $3.0(0.9)$ & & & & \\
\hline & Multi & $2.8(0.2)$ & $2.9(0.2)$ & $3.2(0.2)$ & & & & \\
\hline
\end{tabular}

\footnotetext{
${ }^{\mathrm{a}, \mathrm{b}, \mathrm{c}}$ For significant interactions, different superscripts indicate a significant difference $(P<0.05)$ between means within row.

$*, * *$ For significant interactions, means significantly different $(* P<0.05 ; * * P<0.10)$ between parity or MF routine within period.

${ }^{1} \mathrm{G}_{4-8}=$ Treatment group subjected to the high milking frequency routine in periods 1 and 2 and to the low milking frequency routine in period $3 ; \mathrm{G}_{8-4}=$ treatment group subjected to the low milking frequency routine in periods 1 and 2 and to the high milking frequency routine in period 3; Multi = multiparous; Primi $=$ primiparous .
}

\section{Measures Related to Feeding Patterns}

In period 1 and period 2, cows in $\mathrm{G}_{4-8}$ fed in fewer meals per day than did cows in $\mathrm{G}_{8-4}$ and had longer meals than for cows in $\mathrm{G}_{8-4}$ (Table 3). In period 2, $\mathrm{G}_{4-8}$ cows had more visits per meal than did $\mathrm{G}_{8-4}$ cows. The $\mathrm{G}_{4-8}$ animals had longer meals and a greater number of feeding visits per meal in period 2 compared with period 1 . Both groups significantly changed their feeding patterns when subjected to the new traffic routine in period 3 . In periods 1 and 2 , feeding rate of the mixed feed was 104.5 and $101.4 \mathrm{~g}$ of $\mathrm{DM} / \mathrm{min}$ for $\mathrm{G}_{4-8}$ and $\mathrm{G}_{8-4}$ cows, respectively.

There were no significant differences between parities for number of meals per day, but primiparous cows had longer meals than did multiparous cows in period 2. Primiparous cows had more feeding visits per meal than multiparous cows had in all 3 periods of the study. Primiparous cows had shorter meals and fewer feeding visits per meal in period 1 compared with period 2 .

\section{Milking Frequencies and Passages Through Control Gates}

Least squares means of milking frequencies and passages through control gates are presented in Table 3.
There were significant differences in milking frequency and passages through $\mathrm{CG}$ between $\mathrm{G}_{4-8}$ and $\mathrm{G}_{8-4}$ in periods 1 and 2 , and both groups changed their average milking frequencies when subjected to a new milking frequency routine in period 3 . There were no differences between parities in milking frequency and passages through control gates, except for a higher number of milkings for primiparous cows compared with multiparous cows in period 3 . The average number of nonmilking-related passages through the milking unit in periods 2 and 3 was 0.5 and $0.3 \times / d$ for $\mathrm{G}_{4-8}$ and $\mathrm{G}_{8-4}$, respectively. The range of individual means of milking frequency in periods 1 and 2 was 2.5 to 3.9 milkings per $d$ for the $\mathrm{G}_{4-8}$ cows and 1.6 to 2.6 milkings per $d$ for the $\mathrm{G}_{8-4}$ cows.

The distributions of milking interval lengths for $\mathrm{G}_{4-8}$ and $\mathrm{G}_{8-4}$, respectively, are shown in Figure 2. For $\mathrm{G}_{4-8}$, approximately $33 \%$ of the intervals are longer than $8 \mathrm{~h}$, and about $5 \%$ of the intervals are longer than $12 \mathrm{~h}$. For $\mathrm{G}_{8-4}$, approximately $25 \%$ of the intervals were longer than $12 \mathrm{~h}$. Some intervals were shorter than what should be possible from the preset milking permissions. This was the result of milkings that, for some reason, were incomplete, and after such milkings, the cows still had permission to be milked. The correspond- 
Table 3. Least squares means and standard errors (SE) for cows of different milking frequency treatments (MF) and parities (PA) for daily number of milkings (MI), passages through control gates (PAS), meals, meal length (ML), DM intake per meal (DMI), and feeding visits per meal. Data presented for each period (P).

\begin{tabular}{|c|c|c|c|c|c|c|c|c|}
\hline & \multirow[b]{2}{*}{$\mathrm{MF} / \mathrm{PA}^{1}$} & \multicolumn{3}{|c|}{ Period } & \multicolumn{3}{|c|}{ Type II SS $P>\mathrm{F}$} & \multirow[b]{2}{*}{$\mathrm{A} \times \mathrm{P}$} \\
\hline & & $\begin{array}{l}1 \\
\text { (wk 5-10) }\end{array}$ & $\begin{array}{l}2 \\
\text { (wk 11-16) }\end{array}$ & $\begin{array}{l}3 \\
\text { (wk 18-19) }\end{array}$ & $\mathrm{MF}$ & PA & $\mathrm{MF} \times \mathrm{P}$ & \\
\hline \multirow[t]{4}{*}{ MI, no./d } & $\mathrm{G}_{4-8}$ & $3.3(0.1)^{\mathrm{a} *}$ & $3.1(0.1)^{\mathrm{a} *}$ & $1.9(0.1)^{\mathrm{b} *}$ & \multirow[t]{4}{*}{0.03} & \multirow[t]{4}{*}{0.41} & \multirow[t]{4}{*}{0.001} & \multirow[t]{4}{*}{0.001} \\
\hline & $\mathrm{G}_{8-4}$ & $2.2(0.1)^{\mathrm{b}}$ & $2.1(0.1)^{\mathrm{b}}$ & $3.1(0.1)^{\mathrm{a}}$ & & & & \\
\hline & Primi & $2.7(0.1)^{\mathrm{a}}$ & $2.6(0.1)^{\mathrm{a}}$ & $2.7(0.1)^{\mathrm{a} *}$ & & & & \\
\hline & Multi & $2.8(0.1)^{\mathrm{a}}$ & $2.7(0.1)^{\mathrm{a}}$ & $2.3(0.1)^{\mathrm{b}}$ & & & & \\
\hline \multirow[t]{4}{*}{ PAS, no./d } & $\mathrm{G}_{4-8}$ & $2.8(0.6)^{\mathrm{a} *}$ & $3.2(0.6)^{\mathrm{a} *}$ & $5.1(0.7)^{\mathrm{b}}$ & \multirow[t]{4}{*}{0.06} & \multirow[t]{4}{*}{0.78} & \multirow[t]{4}{*}{0.001} & \multirow[t]{4}{*}{0.02} \\
\hline & $\mathrm{G}_{8-4}$ & $6.5(0.6)^{\mathrm{a}}$ & $5.9(0.6)^{\mathrm{a}}$ & $3.8(0.7)^{\mathrm{b}}$ & & & & \\
\hline & Primi & $5.1(0.8)^{\mathrm{a}}$ & $4.4(0.8)^{\mathrm{b}}$ & $4.6(0.8)^{b}$ & & & & \\
\hline & Multi & $4.2(0.5)^{\mathrm{a}}$ & $4.6(0.5)^{\mathrm{a}}$ & $4.4(0.6)^{\mathrm{a}}$ & & & & \\
\hline \multirow[t]{4}{*}{ Meals, no./d } & $\mathrm{G}_{4-8}$ & $5.3(0.4)^{\mathrm{a} *}$ & $4.9(0.4)^{\mathrm{a} *}$ & $5.7(0.5)^{\mathrm{b}}$ & \multirow[t]{4}{*}{0.04} & \multirow[t]{4}{*}{0.87} & \multirow[t]{4}{*}{0.001} & \multirow[t]{4}{*}{0.15} \\
\hline & $\mathrm{G}_{8-4}$ & $7.2(0.4)^{\mathrm{a}}$ & $6.8(0.4)^{\mathrm{a}}$ & $5.9(0.5)^{b}$ & & & & \\
\hline & Primi & $6.5(0.5)$ & $5.9(0.5)$ & $5.7(0.6)$ & & & & \\
\hline & Multi & $6.0(0.4)$ & $5.8(0.4)$ & $5.9(0.4)$ & & & & \\
\hline \multirow[t]{4}{*}{$\mathrm{ML}, \min$} & $\mathrm{G}_{4-8}$ & $53.7(3.9)^{\mathrm{a} *}$ & $59.4(3.9)^{\mathrm{b} *}$ & $54.3(4.4)^{\mathrm{ab}}$ & \multirow[t]{4}{*}{0.14} & \multirow[t]{4}{*}{0.11} & \multirow[t]{4}{*}{0.001} & \multirow[t]{4}{*}{0.36} \\
\hline & $\mathrm{G}_{8-4}$ & $43.2(3.9)^{\mathrm{a}}$ & $44.9(3.9)^{\mathrm{a}}$ & $54.9(4.3)^{\mathrm{b}}$ & & & & \\
\hline & Primi & $52.0(4.7)^{\mathrm{a}}$ & $57.3(4.7)^{\mathrm{b} * *}$ & $60.2(5.2)^{b}$ & & & & \\
\hline & Multi & $44.9(3.3)^{\mathrm{a}}$ & $47.0(3.3)^{\mathrm{a}}$ & $48.9(3.7)^{\mathrm{a}}$ & & & & \\
\hline \multirow[t]{4}{*}{ DMI, kg/meal } & $\mathrm{G}_{4-8}$ & $4.2(0.3)^{\mathrm{a} *}$ & $4.8(0.3)^{\mathrm{b} *}$ & $3.9(0.3)^{\mathrm{a}}$ & \multirow[t]{4}{*}{0.14} & \multirow[t]{4}{*}{0.08} & \multirow[t]{4}{*}{0.001} & \multirow[t]{4}{*}{0.26} \\
\hline & $\mathrm{G}_{8-4}$ & $3.3(0.3)^{\mathrm{a}}$ & $3.6(0.3)^{\mathrm{a}}$ & $4.4(0.3)^{\mathrm{b}}$ & & & & \\
\hline & Primi & $3.3(0.3)^{\mathrm{a} *}$ & $3.9(0.3)^{\mathrm{b}}$ & $3.8(0.4)^{b}$ & & & & \\
\hline & Multi & $4.2(0.2)^{\mathrm{a}}$ & $4.5(0.2)^{\mathrm{a}}$ & $4.5(0.3)^{\mathrm{a}}$ & & & & \\
\hline \multirow[t]{4}{*}{ Visits, no./meal } & $\mathrm{G}_{4-8}$ & $12.2(0.6)^{\mathrm{a}}$ & $13.7(0.6)^{\mathrm{b} *}$ & $12.3(0.75)^{\mathrm{ab}}$ & \multirow[t]{4}{*}{0.35} & \multirow[t]{4}{*}{0.02} & 0.001 & 0.59 \\
\hline & $\mathrm{G}_{8-4}$ & $11.1(0.6)^{\mathrm{a}}$ & $11.3(0.6)^{\mathrm{a}}$ & $13.5(0.7)^{\mathrm{b}}$ & & & & \\
\hline & Primi & $12.6(0.8)^{\mathrm{a} *}$ & $13.8(0.8)^{\mathrm{b} *}$ & $14.1(0.9)^{\mathrm{b} *}$ & & & & \\
\hline & Multi & $10.7(0.5)$ & $11.3(0.5)$ & $11.7(0.6)$ & & & & \\
\hline
\end{tabular}

\footnotetext{
${ }^{\mathrm{a}, \mathrm{b}, \mathrm{c}}$ For significant interactions, different superscripts indicate a significant difference $(P<0.05)$ between means within row.

****For significant interactions, means significantly different $(* P<0.05 ; * * P<0.10)$ between parity or MF routine within period.

${ }^{1} \mathrm{G}_{4-8}=$ Treatment group subjected to the high milking frequency routine in periods 1 and 2 and to the low milking frequency routine in period $3 ; \mathrm{G}_{8-4}=$ treatment group subjected to the low milking frequency routine in periods 1 and 2 and to the high milking frequency routine in period 3; Multi = multiparous; Primi $=$ primiparous
}
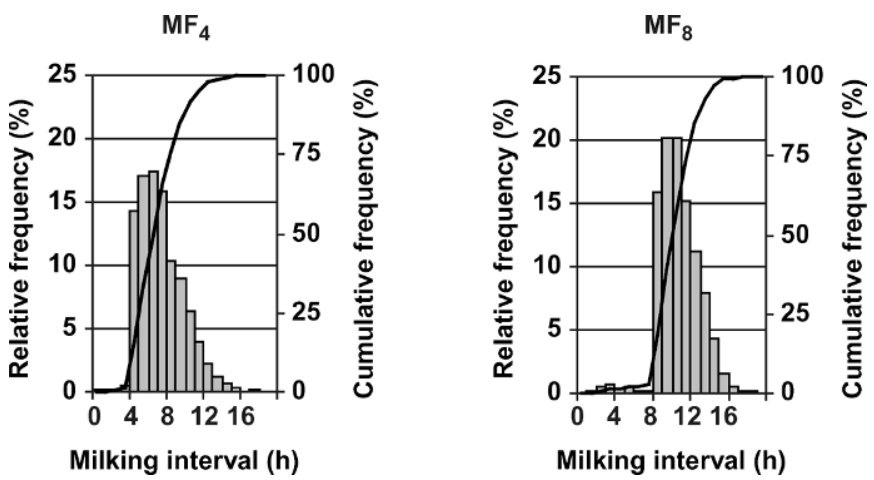

Figure 2. Distribution of milking intervals for $\mathrm{MF}_{4}$ (milking frequency routine with a minimum milking interval of $4 \mathrm{~h} ; \mathrm{n}=3448$ and $\mathrm{MF}_{8}$ (milking frequency routine with a minimum milking interval of $8 \mathrm{~h} ; \mathrm{n}=2388$ ). The bars represent the relative frequency for class widths of $1.0 \mathrm{~h}$. The line represents the cumulative frequency. Data were pooled for periods 1 and 2 (wk 5 to 16 in lactation). ing distributions of daily milking frequencies are shown in Figure 3. Roughly 37\% of the observed daily milking frequencies were $>3$ for $\mathrm{G}_{4-8}$ and $25 \%$ of the observed frequencies were $>2$ for $\mathrm{G}_{8-4}$. The proportion of fetched milkings was $5 \%$ for $\mathrm{G}_{4-8}$ and $2.9 \%$ for $\mathrm{G}_{8-4}$ in periods 1 and 2 .

\section{Return Time and Redirection Time}

The distributions of return time are shown for both groups in Figure 4. When the cows of $\mathrm{G}_{4-8}$ returned from the resting area and registered in a control gate, the registration occurred within $4 \mathrm{~h}$ of the last milking in $85 \%$ of the observations. The corresponding figure for $\mathrm{G}_{8-4}$ was $67 \%$. For $\mathrm{G}_{8-4}, 98.6 \%$ of the registrations occurred within $8 \mathrm{~h}$ of the last milking. The cumulative distribution of $\mathrm{G}_{4-8}$ was steeper compared with that of $\mathrm{G}_{8-4}$. The mean return times were 3.2 (SD 1.2) $\mathrm{h}$ for $\mathrm{G}_{4-8}$ and 3.5 (SD 1.5) $\mathrm{h}$ for $\mathrm{G}_{8-4}$. The range of individual means of return time in periods 1 and 2 was 2.1 to 4.9 $h$ for all cows in the study. 

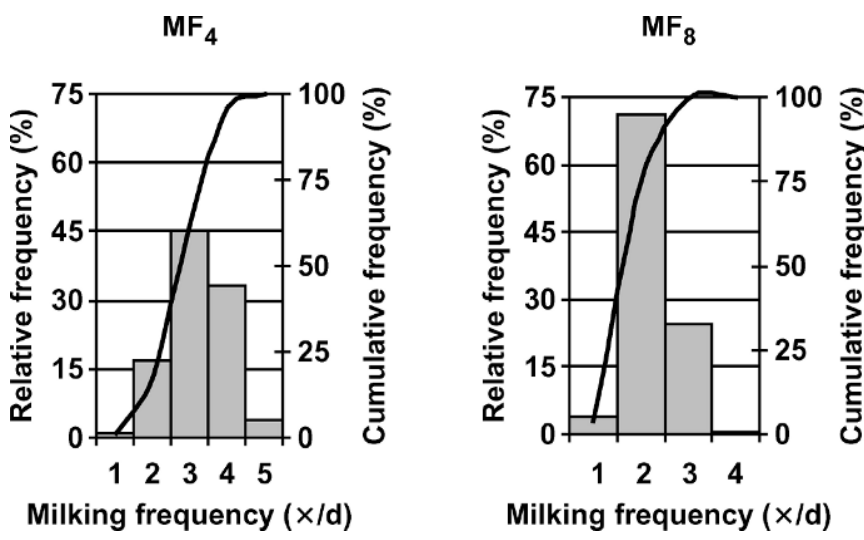

Figure 3. Distribution of cow days with a certain milking frequency for $\mathrm{MF}_{4}$ (milking frequency routine with a minimum milking interval of $4 \mathrm{~h} ; \mathrm{n}=1072$ ) and $\mathrm{MF}_{8}$ (milking frequency routine with a minimum milking interval of $8 \mathrm{~h} ; \mathrm{n}=1077$ ). The bars represent the relative frequency for class widths of 1 milking. The line represents the cumulative frequency. Data were pooled for periods 1 and 2 (wk 5 to 16 in lactation).

The distribution of redirection time showed an abundance of short times for both groups. The $\mathrm{G}_{4-8}$ had redirection times shorter than $1 \mathrm{~h}$ in $48 \%$ of the observations, and the corresponding figure for $\mathrm{G}_{8-4}$ was $63 \%$. The mean redirection time was 1.0 (SD 0.1) $\mathrm{h}$ for $\mathrm{G}_{4-8}$ and 0.64 (SD 0.1) $\mathrm{h}$ for $\mathrm{G}_{8-4}$. The range of individual means of redirection time in periods 1 and 2 was 0.2 to $2.9 \mathrm{~h}$ for all cows in the study.

\section{DISCUSSION}

One important argument for farmers in favor of making an investment in AMS is that these systems allow for increased milking frequency that in turn increases
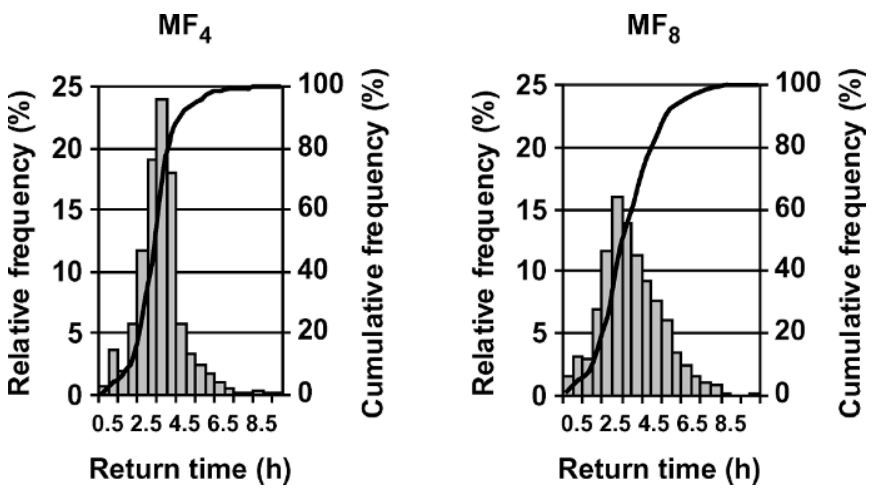

Figure 4. Distribution of return time for $\mathrm{MF}_{4}$ (milking frequency routine with a minimum milking interval of $4 \mathrm{~h} ; \mathrm{n}=1050$ ) and $\mathrm{MF}_{8}$ (milking frequency routine with a minimum milking interval of $8 \mathrm{~h}$; $\mathrm{n}=1472$ ). The bars represent the relative frequency for class widths of $0.5 \mathrm{~h}$. The line represents the cumulative frequency. Data are presented for periods 1 and 2 (wk 5 to 16 in lactation). milk yield without additional labor. In the present study, the milking permission settings were successful in creating a milking frequency difference between treatment groups; in periods 1 and $2, \mathrm{G}_{4-8}$ cows were milked $3.2 \times$ and $\mathrm{G}_{8-4}$ cows were milked $2.3 \times$ per day. When milking permission settings were switched between treatment groups in period 3, the groups quickly adapted to the new milking frequencies, suggesting that control gates are good tools in guiding cows to target milking frequencies (Table 3). However, the milking permission settings allowed for a theoretical maximum milking frequency of $6 \times$ during $\mathrm{MF}_{4}$, which was far from the actual milking frequency. It can be concluded that average milking frequencies much above $3 \times$ are probably not realistic in an AMS such as that used in this study. However, it is important to stress that individual differences in milking frequency existed. Cow traffic studies performed with a low number of cows have resulted in a high number of voluntary visits to the milking unit (Devir and Maltz, 1995; Ketelaar-deLauwere et al., 1998). The total numbers of social interactions between cows have likely been lower in the earlier studies, and the results are therefore not equivalent to the present study and other studies with higher number of cows (e.g., Harms et al., 2002; Thune et al., 2002).

It could be argued that the $300 \mathrm{~g}$ of concentrate given at every milking was too low for attracting the cows to the milking unit. The effect that the amount of concentrate fed in the milking unit has on voluntary milkings is not conclusive. In 1 of 3 European regions surveyed, Van't Land et al. (2000) found a positive relationship between the amount of concentrate fed in the milking unit and number of voluntary visits to the milking unit. Such an effect was not found by Rodenburg and Wheeler (2002) and Halachmi (2004).

To successfully guide cows toward target milking frequencies, 2 prerequisites must be fulfilled; 1) the cows must frequently show up in the control gates; 2) the time from a redirection in the gates until showing up for milking must be short. Successful guiding of cow toward target milking frequencies is an essential part in an individual approach to management in AMS. Maltz et al. (2002) outlined an individual management strategy of dairy cows in AMS, in which milking frequency and concentrate supplementation were adjusted according to the physiological status of each cow.

In the present study, we measured return time, which was the interval between a milking and the first attempt to make a nonmilking-related meal by register in the control gates. Return time was assumed related to the voluntary interval between the first and the second meal in the milk cycle (milking to milking). Return times as short as those observed in the present study 

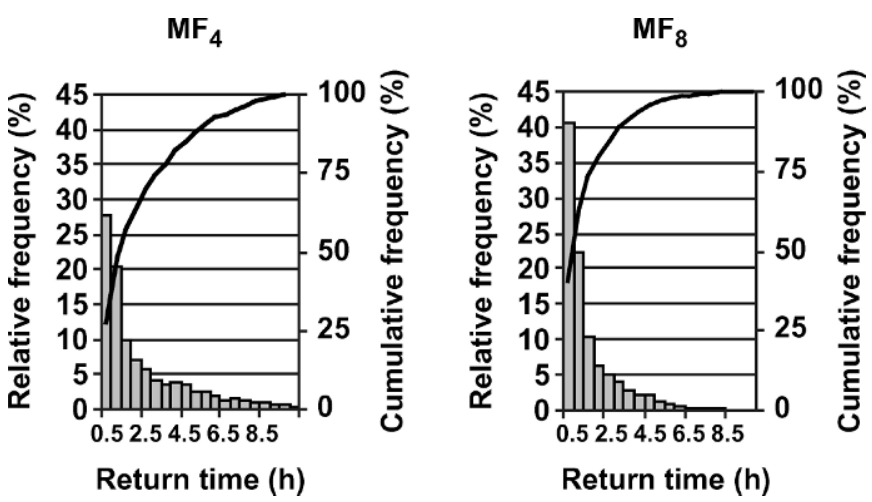

Figure 5. Distribution of redirection time for $\mathrm{MF}_{4}$ (milking frequency routine with a minimum milking interval of $4 \mathrm{~h} ; \mathrm{n}=1445$ ) and $\mathrm{MF}_{8}$ (milking frequency routine with a minimum milking interval of $8 \mathrm{~h} ; \mathrm{n}=1923)$. The bars represent the relative frequency for class widths of $0.5 \mathrm{~h}$. The line represents the cumulative frequency. Data are presented for periods 1 and 2 (wk 5 to 16 in lactation).

should, with an efficient redirection system, have allowed for very high milking frequencies. In addition, the cows in both milking frequency routines used the control gates frequently. It can be concluded that the first prerequisite above was fulfilled by the cow traffic system in the present study. One reason for a lower than expected milking frequency was that redirection times were frequently very long (Figure 5 ). The second prerequisite above was not fulfilled by the cow traffic system in the present study with an open waiting area in front of entrance to the milking unit. We have observed that cows of low social rank left the waiting area and headed toward the resting area when there were already more than 3 cows waiting in front of the milking unit (data not shown). The proportion of fetched milkings was rather low in both milking frequency routines. However, the proportion that was overdue for milking, which is a measure not influenced by the fetching routine, was higher in $\mathrm{MF}_{4}$ compared with the $\mathrm{MF}_{8}$ cows.

The $\mathrm{MF}_{4}$ routine caused the cows to displace the distribution of return time toward the time limit in control gates of $4 \mathrm{~h}$. The cows seem to have learned when the gates were about to close and apparently reduced the interval between the first and the second meal in the milking cycle. This observation suggests that the onset of a meal involves a factor related to the cows' past experience and learning. This is quite likely because it has been found that cows can learn and quickly adapt to new concentrate feeding routines (Livshin et al., 1995). Because of the wide individual range that was found in average return time, the fixed-time settings on a group level have no justifiable biological basis. We suggest that the number of nonmilking-related meals the cow achieves in every milking cycle is more relevant for controlling the gates than is the elapsed time since last milking.

The control gates were used efficiently in both cow traffic routines, with only a few passages through gates not resulting in actual meals. Because of the long redirection times in the present study, $\mathrm{MF}_{4}$ limited the number of daily meals the cows could have. Intake is determined by the digestibility and passage rate in the rumen (Faverdin et al., 1995), and prolonged meal intervals (caused by long redirection times) could explain the higher feed intake per meal during $\mathrm{MF}_{4}$. However, Tolkamp et al. (2002) found evidence that meal size is not limited by rumen fill, and it is likely that metabolic signals regulated the size of meals in the present study.

The total amount of feed consumed per day by the cows during $\mathrm{MF}_{4}$ was as high as the amount consumed by the cows during $\mathrm{MF}_{8}$. However, it can be argued that increased DMI should have been expected when milking increased from $2 \times$ to $3 \times$ a day (Bar-Peled et al., 1995). However, there are milking frequency trials showing no such increase in DMI (DePeters et al., 1985). When the degree of controlled cow traffic is increased, an increased time spent queuing in front of the milking unit is often observed (Ketelaar-deLauwere et al., 1998; Thune et al., 2002). This time must be accounted for in the dairy cow's daily time budget, and it could be argued that time limited the DMI of the cows during $\mathrm{MF}_{4}$. However, the similar feeding rates of cows in the different cow traffic routines indicated that time was not limiting feed intake. In addition, the increase in body condition during the study indicates that $\mathrm{G}_{4-8}$ cows did not mobilize body reserves for milk production, suggesting that they had no drive for a further increase in feed intake.

If the length of redirection time depends on the cows' motivation and ability to advance in the queue in front of the milking unit, it seems as though the cows in $\mathrm{G}_{8-4}$ were more motivated to advance in the queue than were cows in $\mathrm{G}_{4-8}$ (Figure 5). When $\mathrm{G}_{8-4}$ cows were redirected, a longer time had passed since the last milking than when the $\mathrm{G}_{4-8}$ cows were redirected. Whether the degree of udder fill is an incentive to advance faster in the queue is purely speculative and the idea is in conflict with the view that milking is a low incentive for visiting the milking unit (Prescott et al., 1998).

Primiparous cows have had limited experience with the AMS when they were introduced after parturition. In general, primiparous cows are low ranked when introduced to a herd (Wierenga, 1990), and it can be hypothesized that they would encounter difficulties in getting access to the barn facilities. In the first period of the present study, the milking frequency and the number of passages through control gates for the primiparous cows were as high as for the multiparous cows, showing 
that primiparous cows had adapted well to the system. The first $2 \mathrm{wk}$ were not included in the analysis, and the situation for primiparous cows during those weeks remains unanswered. Primiparous cows paid more visits to the feeding stations and had longer average meal times. This indicates that primiparous cows were more often disrupted during feeding. Disruption in feeding is common when cows of low social rank have to compete for feeding space (Olofsson, 1999). The differences in meal length and DMI per meal between periods 1 and 2 for primiparous cows are likely related to changes due to the lactation stage rather than indications of adaptation problems.

\section{CONCLUSIONS}

With control gates and an open waiting area in front of the milking unit, a difference of one milking per day between treatment groups was achieved, which resulted in a milk yield increase of about $9 \%$. Yield differences were not as evident for ECM but relative yields changed when the milking frequencies were shifted between groups. The cows had short voluntary intervals between the first and the second meals in the milking cycle, which could have allowed for a very high number of voluntary visits to the feeding area. However, the observed redirection times were sometimes very long, which in turn prolonged the milking intervals and prohibited a high average milking frequency. In addition, there was high variation between individual means of milking frequency. The $\mathrm{MF}_{4}$ limited the number of meals the cows could get per day, but longer meal intervals allowed for a higher feed intake per meal. Although the $\mathrm{G}_{4-8}$ cows had higher milk yield in periods 1 and 2 than cows in $\mathrm{G}_{8-4}$, both groups had similar feed intakes. Similar feeding rates between groups discounted the possibility that long redirection times would have limited feed intake during $\mathrm{MF}_{4}$. A wide individual range in return time suggests that time limits in control gates set on group-level have no justifiable biological basis. It was concluded that primiparous cows were well adapted to the AMS after 2 wk in the barn.

\section{ACKNOWLEDGMENTS}

The assistance of animal technician Gunilla Helmersson with the management of cows and Gunnar Pettersson with data collection and handling at the Department of Animal Nutrition and Management are gratefully acknowledged. This project was financed by DeLaval AB and Swedish Farmers' Foundation for Agricultural Sciences.

\section{REFERENCES}

Bar-Peled, U., E. Maltz, I. Bruckental, Y. Folman, Y. Kali, H. Gacitua, A. R. Lehrer, C. H. Knight, B. Robinzon, H. Voet, and H. Tagari. 1995. Relationship between frequent milking or suckling in early lactation and milk production of high producing dairy cows. J. Dairy Sci. 78:2726-2736.

DePeters, E. J., N. E. Smith, and J. Acedo-Rico. 1985. Three or two times daily milking of older cows and first lactation cows for entire lactations. J. Dairy Sci. 68:123-132.

Devir, S., and E. Maltz, 1995. Dairy cow performace under full individual automatic management in the milking robot farm. Pages 108 128 in The dairy control and management system in the robotic milking farm. Ph.D. Thesis (S. Devir), Wageningen Agricultural University, The Netherlands.

Drackley, J. K. 1999. Biology of dairy cows during the transition period: The final frontier? J. Dairy Sci. 82:2259-2273.

Faverdin, P., R. Baumont, and K. L. Ingvartsen. 1995. Control and prediction of feed intake in ruminants. Pages 95-120 in Recent developments in the nutrition of herbivores: Proc. 4th Int. Symp., Clermont-Ferrand, France. INRA Editions, Paris, France.

Halachmi, I. 2004. Managing an automatic milking farm: Minimizing the amount of concentrates in the robot. Page 489 in Automatic milking: A better understanding. Conference Proceedings, Lelystad, The Netherlands. Wageningen Academic Publishers, Wageningen, The Netherlands.

Halachmi, I., J. H. M. Metz, E. Maltz, A. A. Dijkhuizen, and L. Speelman. 2000. Designing the optimal robotic milking bar, Part 1: Quantifying facility usage. J. Agric. Eng. Res. 76:37-49.

Harms, J., G. Wendl, and H. Schön. 2002. Influence of cow traffic on milking and animal behaviour in a robotic milking system. Pages II-8-II-14 in Proc. 1st North Am. Conf. Robotic Milking. Wageningen Pers, Wageningen, The Netherlands.

Hermans, G. G. N., A. H. Ipema, J. Stefanowska, and J. H. M. Metz. 2003. The effect of two traffic situations on the behavior and performance of cows in an automatic milking system. J. Dairy Sci. 86:1997-2004.

Ketelaar-deLauwere, C. C., M. M. W. B. Hendriks, J. H. M. Metz, and W. G. P. Schouten. 1998. Behaviour of dairy cows under free or forced cow traffic in a simulated automatic milking system environment. Appl. Anim. Behav. Sci. 56:13-28.

Livshin, N., E. Maltz, and Y. Edan. 1995. Regularity of dairy cow feeding behavior with computer-controlled feeders. J. Dairy Sci. 78:296-304

Maltz, E., N. Livshin, D. Rosenfeld, and S. Devir. 2002. Using online data in individual milking frequency and concentrates supplementation in the AMS herd. Pages III-33-III-44 in Proc. 1st North Am. Conf. Robotic Milking. Wageningen Pers, Wageningen, The Netherlands.

Metz, J. H. M. 1975. Time patterns of feeding and rumination in domestic cattle. Meded. Landbouwhogesch. 75-12, Agric. Univ., Wageningen, The Netherlands.

Melin, M., H. Wiktorsson, and L. Norell. 2005. Analysis of feeding and drinking patterns of dairy cows in two cow traffic situations in automatic milking systems. J. Dairy Sci. 88:71-85.

Olofsson, J. 1999. Competition for total mixed diets fed for ad libitum intake using one or four cows per feeding station. J. Dairy Sci. 82:69-79.

Poelarends, J. J., O. C. Sampimon, F. Neijenhuis, J. D. H. M. Miltenburg, J. E. Hillerton, J. Dearing, and C. Fossing. 2004. Cow factors related to the increase of somatic cell count after introduction of automatic milking. Pages 148-154 in Automatic milking: A better understanding. Conference Proceedings, Lelystad, Netherlands. Wageningen Academic Publishers, Wageningen, The Netherlands.

Prescott, N. B., T. T. Mottram, and A. J. F. Webster. 1998. Relative motivations of dairy cows to be milked or fed in a Y-maze and an automatic milking system. Appl. Anim. Behav. Sci. 57:23-33.

Rodenburg, J., and B. Wheeler. 2002. Strategies for incorporating robotic milking into north American herd management. Pages III-18-III-32 in Proc. 1st North Am. Conf. Robotic Milking. Wageningen Pers, Wageningen, The Netherlands. 
SAS Institute. 1999. SAS System for Windows, Release 8.02. SAS Inst., Inc., Cary, NC.

Sjaunja, L. O., L. Baevre, L. Junkarinen, J. Pedersen, and J. Setälä. 1990. A Nordic Proposal for an Energy Corrected Milk (ECM) formula. ICPMA, 27th session, Paris, France. International Committee for Recording the Productivity of Milk Animals.

Spörndly, R. 1999. Fodertabeller för idisslare. Report 247, Dept. of Animal Nutrition and Management, Swedish University of Agricultural Sciences, Uppsala, Sweden. (In Swedish)

Svennersten-Sjaunja, K., I. Berglund, and G. Pettersson. 2000. The milking process in an automatic milking system, evaluation of milk yield, teat condition and udder health. Pages 277-287 in Robotic milking-Proc. Int. Symp., Lelystad, The Netherlands. Wageningen Pers, Wageningen, The Netherlands.

Thune, R. O., A. M. Berggren, L. Gravas, and H. Wiktorsson. 2002. Barn layout and cow traffic to optimise the capacity of an auto- matic milking system. Pages II-45-II-50 in Proc. 1st North Am. Conf. Robotic Milking. Wageningen Pers, Wageningen, The Netherlands.

Tolkamp, B. J., N. C. Friggens, G. C. Emmans, I. Kyriazakis, and J. D. Oldham. 2002. Meal patterns of dairy cows consuming mixed foods with a high or a low ratio of concentrate to grass silage. Anim. Sci. 74:369-382.

Van't Land A., A. C. van Lenteren, E. van Schooten, C. Bouwmans, D. J. Gravesteyn, and P. Hink. 2000. Effects of husbandry systems on the efficiency and optimisation of robotic milking performance and management. Pages 167-176 in Robotic milking-Proc. Int. Symp., Lelystad, The Netherlands. Wageningen Pers, Wageningen, The Netherlands.

Wierenga, H. K. 1990. Social dominance in dairy cattle and the influences of housing and management. Appl. Anim. Behav. Sci. $27: 201-229$ 